\title{
IMPROVEMENT OF EQUIPMENT FOR PLASMA LUBRICATION OF GAS-TURBINE ENGINES AND INSTALLATIONS
}

\author{
Volodymyr Lebedev'; Serhiy Loi ${ }^{2}$; Oleksiy Khalimovskyy ${ }^{3}$
}

\author{
${ }^{1}$ E. O. Paton Electric Welding Institute of National Academy of Sciences of \\ Ukraine, Kyiv, Ukraine \\ ${ }^{2}$ Kherson branch of Nikolaev Shipbuilding University named after. Admiral \\ Makarov, Kherson, Ukraine \\ ${ }^{3}$ National Technical University of Ukraine «Igor Sikorsky Kyiv Polytechnic \\ Institute», Kyiv, Ukraine
}

\begin{abstract}
Summary. New design solutions for equipment for plasma spraying of gas turbine engine blades and plants have been developed. The use of such equipment allows to expand the scope of its application to create optimal conditions for the transfer of material, which is poured on the work surface of the product. This improves the physical characteristics and structure of the spray layer. The basic directions of improvement of technology and technology of plasma spraying on the examples of a number of new effective developments are considered. The conclusion is made that multi-sectional designs of plasma torches are more effective than traditional solutions. Plasma spray equipment modernization is carried out for two main types of plasma torches: for air spraying and for spraying in a controlled atmosphere (in a vacuum). On the basis of the plasma torch PN-14M developed its advanced design to eliminate structural deficiencies. The proposed design solutions have made it possible to make the structure versatile in terms of the application environment. The modernized plasma torch has a relatively small flow of plasma-gas in operating modes. A specially designed nozzle for a plasma torch of the second type, which is used to spray in a controlled atmosphere, has improved its operational properties. An even supply of powder to the plasma torch is realized with the help of a new design. When sprayed in a controlled atmosphere, the powdered cavity provides uniform dispersion of powder for more than 40 microns. The use of the valve engine is proposed to reduce (absence) of the dipping of the powder. The research of the developed system of automatic control of the position of the shaft of the valve engine was carried out in the frequency range of the pulse signal of the task up to $20 \mathrm{~Hz}$. The results of the mathematical modeling proved the possibility of using the valve engine in the pulse mode of its operation to control the dosage of the powder supply to the plasma torch and to control the work and installation displacements of the device manipulators for plasma spraying.
\end{abstract} technology.

Key words: plasma spraying, blade, gas turbine engine, installation, process, refinement, technique,

Introduction. Technique and technology of plasma spraying of working elements of gas turbine engines and plants are constantly being improved and the origins of this are the need for this type of reconstruction and strengthening, new types of materials for spraying, protective environments, new developments of technologies, and in our view, new technical solutions have an effective impact which are mainly based on the capabilities of modern elementary base, components of mechatronics, etc., As a result, the quality of the work results is improved, the equipment is improved and the conditions of the process type in question are expanded [1].

It should be added that the use of plasmatron technologies does not interact only by spraying. It 's welding, cutting, hardening. Thus, a number of instructions for improving the equipment for the implementation of plasma technologies can be general and applied for various processes. 
It can be noted that one of the main areas of improvement of this process is the search for methods and means of improving plasma spraying and the associated expansion of equipment applications to create optimal conditions for transfer of the sprayed material to the working surface, improved structure and physical characteristics of the sprayed layer, including adhesion in the whole period of turbine blades operation; improved power and resource consumption, etc. [2], [3] and, in particular, overall process costs.

The Objective and task. The purpose of this work is to analyse a number of areas of improvement of technique and technical parameters of systems for plasma spraying of certain types of contracts with development of methods of research and control of obtained results using modern methods and corresponding equipment and instruments.

Let 's look at the main directions of improvement of plasma spraying technique and technology on the basis of examples of a number of new effective developments.

Technical innovations in the main units of the plasma sprayed. On Fig. 1. the structural diagram of the plasma spraying plant in the traditional design is presented. The diagram of Fig. 1 does not show in detail the main units of the installation - plasmatrone itself and spraying material dispenser. All this, as well as the elements of the manipulator, will be considered below as modernized devices, at the same time the main tasks of modernization are to improve the quality of the sawn layer, increase productivity, solve reliability problems, increase the service life of both the main nodes and the installations as a whole. The modernization was carried out for two main types of plasmatrons: for spraying in air and for spraying in a controlled atmosphere (in vacuum). Let 's show it on characteristic examples.

It should be noted that in new developments or modernization of plasmatrons only multi-section designs were used in our opinion and according to tests more effective than traditional solutions. In particular, in terms of the possibilities of increasing voltage and therefore power, as a result, increases the quality of spraying and productivity of the plant.

In this work we will consider the areas of improvement of installations on the basis of examples of real installations and specific main nodes of their components.

Modernization of plasmatron for air spraying. For air spraying on the unit is used, reliability and quality of operation of which is determined in basic terms by reliability of plasmatron operation [4]. The experience of the PS-14M-type plasmatron in the spraying of thermal protection coatings has shown that it does not provide the necessary arc power (up to $40 \mathrm{~kW}$ ) and has a number of structural disadvantages: powder supply channels are often clogged; there is great resistance to the passage of cooling water; lower stability of sealing elements; plasmatron design does not provide for its attachment to vacuum chamber.

In an existing plasmatron design, the cooling water flow passes through the anode and then sequentially through the annular channels of each insert. This direction of flow is justified by the design of the caprolon insert, where each annular channel of inserts has a partition and a window.

In order to overcome the above-mentioned disadvantages, an improved design of the plasmatron PS-14M developed on the basis of the plasmatron. In order to improve water cooling of the interelectrode inserts, the design of the caprolon insert has been changed, in which through channels are made in series along the inserts instead of water overflow windows.

The reliability of the cathode is largely determined by the purity of the plasma exhaust gases, the intensity of the cooling and its geometric parameters. In the upgraded design, the tungsten cathode is attached to the collet clamp, allowing the required length of the working part to be easily and timely set. 
Unreliability of the plasmatron is PS-14M determined by the spraying powder supply unit. Sealing rubbers due to overheating often fail what leads to a movement of sealing of the arc channel and causes short circuit of the interelectrode inserts.

In order to avoid overheating of the seals of the outlet nozzle at the point of powder supply, the structure of the anode body and the outlet nozzle is changed. When the inner diameter of the anode body increases, the width of the cooling water channels is in accordance with the line. In addition, instead of one hole for water passage from anode to plasmatrone housing, three channels are provided in the developed design, which reduces heat loading at the powder supply section due to intensive heat removal.

The changes described improved the thermal performance and increased the resistance of the outlet nozzle seals as well as the interelectrode inserts. Insert design is located in front of nozzle differs from others by thickened shoulder. Interelectrode inserts are cooled as water passes through the caprolon insulator. When the inlet pressure is $0.85 \mathrm{MPa}$, the cooling water flow rate is $16 \mathrm{l} / \mathrm{min}$, and the increase in pressure to $0.95 \mathrm{MPa}$ leads to an increase in flow rates to $191 / \mathrm{min}$. With this cooling, the modernized structure works reliably at a power of up to $40 \mathrm{~kW}$.

A significant advantage of the proposed

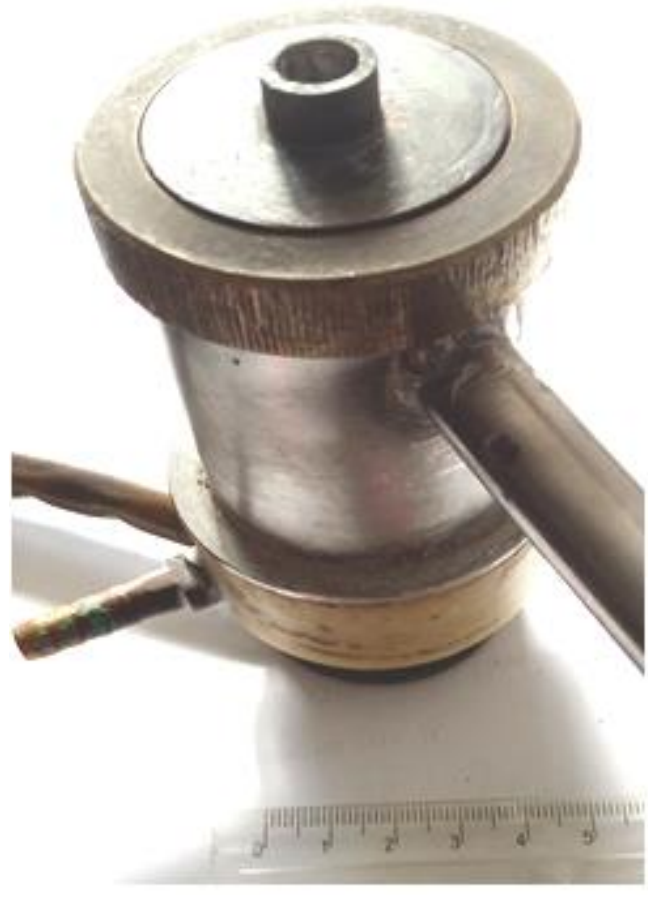

Figure 1. The design of the upgraded plasmatron plasmatron design is the possibility of using a mixture of argon and high-entropy gases (nitrogen or helium) as the plasma-forming gas. At the same time heat adventure of plasmatron elements does not lead to failure of rubber seals of elements.

The powder in this case is fed into the anode spot and is in the nozzle channel for some time, thereby improving the heating of the particles in the plasma jet, which is especially important when spraying in a sparse controlled atmosphere where the speed of the particles reaches $800-1000 \mathrm{~m} / \mathrm{s}$, makes it possible to use the plasmatron design in vacuum spraying. Thus, the design solutions proposed made it possible to develop a universal design with respect to the application environment. Fig. 1 shows the upgraded plasmatron.

A number of plasma technology processes are implemented by feeding powder out materials into plasma jets [5]. However, as the experiments carried out show, not all powder is supplied to the plasma jet, not all melts and vaporizes despite its high heat content. The reasons for the low heating efficiency may be: the short residence time of the particles in the plasma jet, the difficulty of introducing the powder into the central zone of the jet.

Nozzle completion. The wrong putting of the powder can be slippage of it in the seat areas where the gas temperature is low. This results in flooring. When the powder is melted, the caprolon gasket, whose manufacture is rather complicated, often fails. To improve the melting conditions of the powder, the nozzle geometry was changed so that the powder was supplied at an angle of $110^{\circ}$, whereby the heat exchange in the argon powder system was improved due to the longer residence time of the particles in the jet. At the same time, the velocity of the particles will decrease slightly, but when sprayed in a vacuum where the resistance of the medium is low, this factor will not play a determining value due to the increase in the velocity of the particles compared to spraying in the air. Replacement of injection angle of sprayed substances $\left(90^{\circ} \ldots 110^{\circ}\right)$ can be carried out with some change of outlet nozzle 
geometry. As a result, an exit nozzle is proposed which is slightly longer than what is. Besides, nozzle opening angle is changed from $90^{\circ}$ to $60^{\circ}$. A smaller angle to reveal would improve the direction of the jet and the dispersion ratio of the powder material would increase accordingly.

The upgraded plasmatron has relatively low plasma-forming gas costs in operating modes. It provides the necessary operating power sufficient to warm up the particles in a plasma jet when sprayed in a controlled environment.

In order to eliminate these shortcomings, a set of works was carried out the content of which was a deeper modernization of plasmatron. In order to increase the power, the diameter of the plasmatron channel was increased from 6 to $10 \mathrm{~mm}$ with corresponding changes in the sizes of the inter-electrode inserts, the inlet and outlet nozzles, the diameter of the cathode, the capron insulator and the anode and cathode bodies, which allowed to increase the length of the channel more than 1.5 times. These design changes provided increased plasmatron power due to increased arc voltage.

In the upgraded plasmatron, the tungsten cathode is installed in the collet clamp, which allows to set the necessary length of its working part.

In the modernized design, the problems of improving cathode cooling have been solved and geometric dimensions have been optimized on the basis of experimental studies.

In order to increase stability of arc, increased flow rate of plasma-forming gas is provided and cooling of cathode is improved.

Powder feed assembly is changed to prevent superheating of seals, outlet of second nozzle at powder feed point.

Improved water cooling system for plasmatron. The initial nozzle has grooves providing additional heat removal. With this cooling this design works reliably at a power of up to $50 \mathrm{~kW}$.

Analysis of the results showed that the upgraded plasmatron has a sufficiently small plasma-forming gas flow rate during spraying and has a working power sufficient to warm up the particles in a plasma jet in a dynamic vacuum.

It is possible to improve the performance properties of plasmatron specially designed for it nozzle.

When spraying in a deep vacuum, the plasma jet takes blurred shapes and deflects on the way to the substrate, so it is necessary to limit the shape of the plasma jet with its sealing and providing the required direction [7]. Structurally, this function can be performed by a pipenozzle, connected to a plasmatron, but not electrically connected to it. Walls of tube-nozzle limit diameter of plasma jet, at the same time its density and temperature increase.

The powder particles in such a nozzle are better heated and accelerated and therefore the coating quality is improved.

In the upper part the pipe-nozzle must have

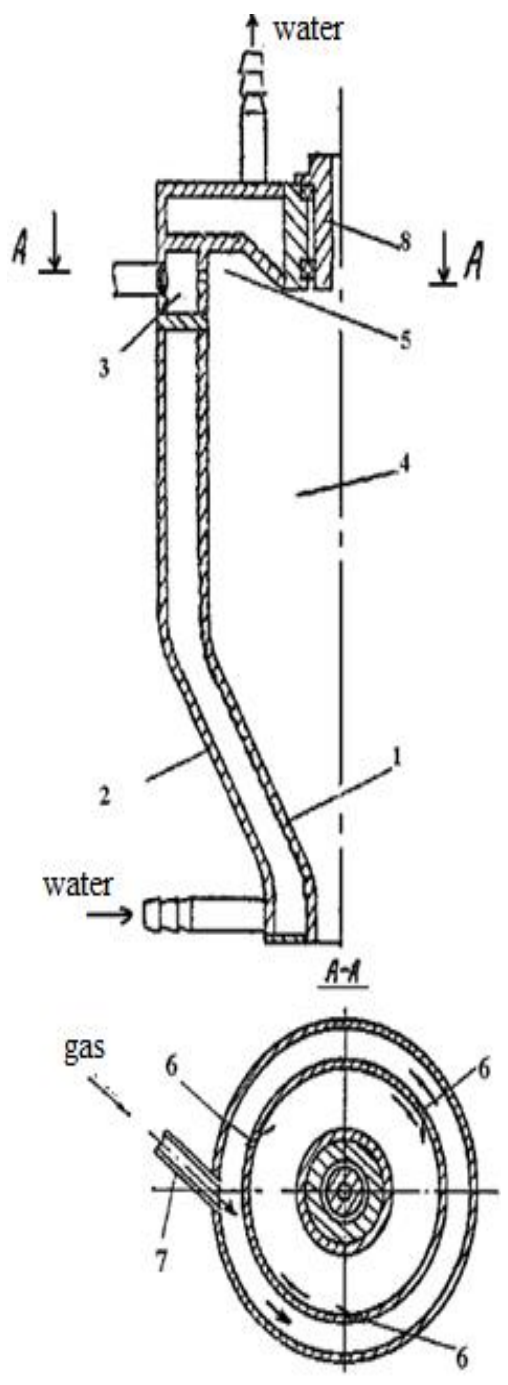

Figure 2. Nozzle for spraying in a rarefied medium: 1 - tube of variable cross section; 2 casing; 3 - ring cavity; 4 extensions, acts as a mixing chamber. In this «chamber», the pulsation of temperature, pressure 
and speed is suppressed, and the powder material is more efficiently mixed with plasma. The sputtering material moves more from a heterogeneous state to a homogeneous state. The material of such a pipe must have a high thermal conductivity, the inner surface of which must be chromized, and longitudinal ribs must be formed on the outer surface to improve heat transfer and stiffness. The nozzles must be water-cooled.

In order to determine the optimal size of the nozzle, a number of experimental tests were carried out, as well as some methods of mathematical modeling of plasmatrons were used [8]. Metal tubes of different lengths and diameters were used.

Coatings which were obtained using a $26 \mathrm{~mm}$ diameter nozzle and $600 \mathrm{~mm}$ length have a sufficiently small porosity of $0.3 \%$, the powder particles in the jet were completely melted.

The design of the developed nozzle is presented in Fig. 2.

The nozzle comprises a variable-section pipe 1, a casing 2 for cooling medium pumping, which encloses the pipe with a small interval. Part of the gap of the transfer-delivery chamber forms an annular cavity 3 enclosing the central channel 4, which has an annular recess 5 . Side channels 6 are adjacent to central channel 4. Gas supplied through tube 7 is heated in annular cavity 3 by means of heat transfer from high-temperature gas-powder flow flowing from plasmatron through nozzle 8 and passing through channels 6 forms free vortex in annular recess.

Proposed design of nozzle makes it possible to have high material utilization factor at low pressure, improves melting of powder particles and makes plasma jet directed.

Powder dispenser (new development). Powder holder, which is a part of the plant is the most important unit on the operation of which the quality of the sprayed layer depends, its density, uniformity and as a result, mechanical properties [9].

Powder blower (Fig. 3) has a body made of organic glass, which allows visual only to observe the movement of powder from the intake cavity to the pipeline, which leads to plazmotron. Cavities of rotor made of hardened stainless steel serve for transfer of powder particles. The feeder bin is made of stainless steel and polished. This simplifies care reduces resistance to powder movement and its nali panel.

In addition, the feeder design includes: rubber gasket and glands in the housing, which prevent air suction; a rubber sealing ring in the slot of the hopper cover to eliminate gas leakage into the atmosphere; gland pressing spring; a gear shaft through which rotational motion is transmitted from the electric motor; attached by means of a bracket to the housing on the gear; a T-joint for distributing gas into the hopper and the powder supply cavity in the housing; washers for pressing of glands; connector for connection of feeder to plasmatron by means of flexible tube. Parts of powder holder are secured by screws. The motor is powered by a voltage of 27 volts DC, ensures safety of operation and facilitates rotation speed change when powder dosage is changed using fairly simple regulators.

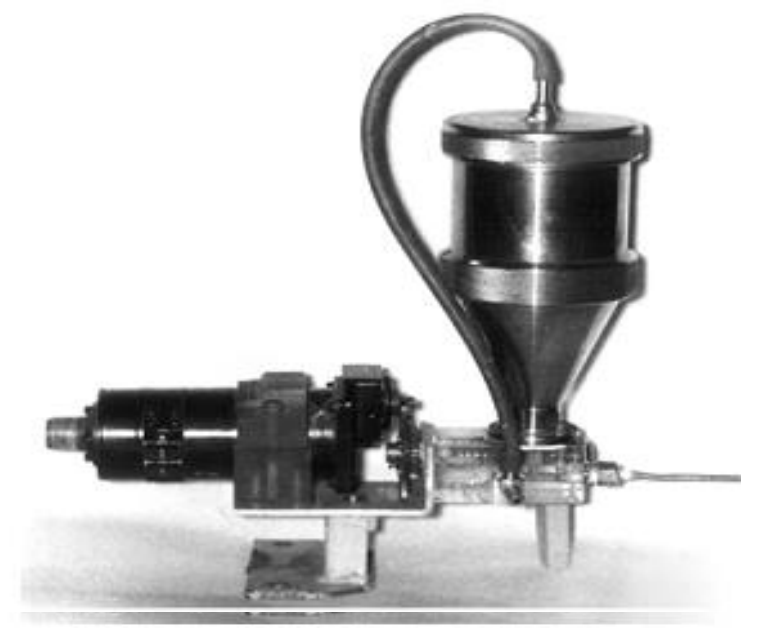

Figure 3. Powder feeder Assembly

The powder holder operates as follows. When the electric motor is switched on, the rotor starts rotating. The powder, under the influence of gravity and vibration inevitable in the operation of any mechanisms descends into the channel above the rotor and fills its slots. Returning to $180^{\circ}$, powder-filled slots turn out to be a low hollow hole, and the powder is poured into it. Gas is supplied to the T-joint into the hopper and creates back pressure, and also, passing 
through the cavity in the housing, captures powder spills through the connector to the plasmatron.

Powder is metered by change of rotor rotation speed, which is controlled by change of voltage supplied to electric motor.

The powder cleaner, the appearance of which is given in Fig. 3, ensures a uniform supply of powders with dispersion of both more and less than $40 \mu \mathrm{m}$ at spraying in a controlled atmosphere. At present, designs are being developed for porous-leather drive with electric motors of non-collector type - stepwise and valve-type with the possibility of obtaining pulse rotation of the electric motor with adjustable parameters, which allows to significantly reduce the mode of powder deposition. Partially, this task is solved by the structures of powder-andliquid drive with eccentric elements connected to the shaft of the electric motor. Pulsed or pulsating rotation of electric motor shaft with specified stable parameters - frequency and amplitude make it possible to precisely dose powder supply and to practically exclude its sticking on walls of powder-and-powder feeder.

Manipulator for plasma spraying installation. We will stop at devices of movement of articles sprayed - manipulators as which are used various devices of coordinate movement using various drive evens of DC and AC current [10], [11].

A schematic representation of the installation with the arrangement of devices for moving the sprayed article is shown in Fig. 4.
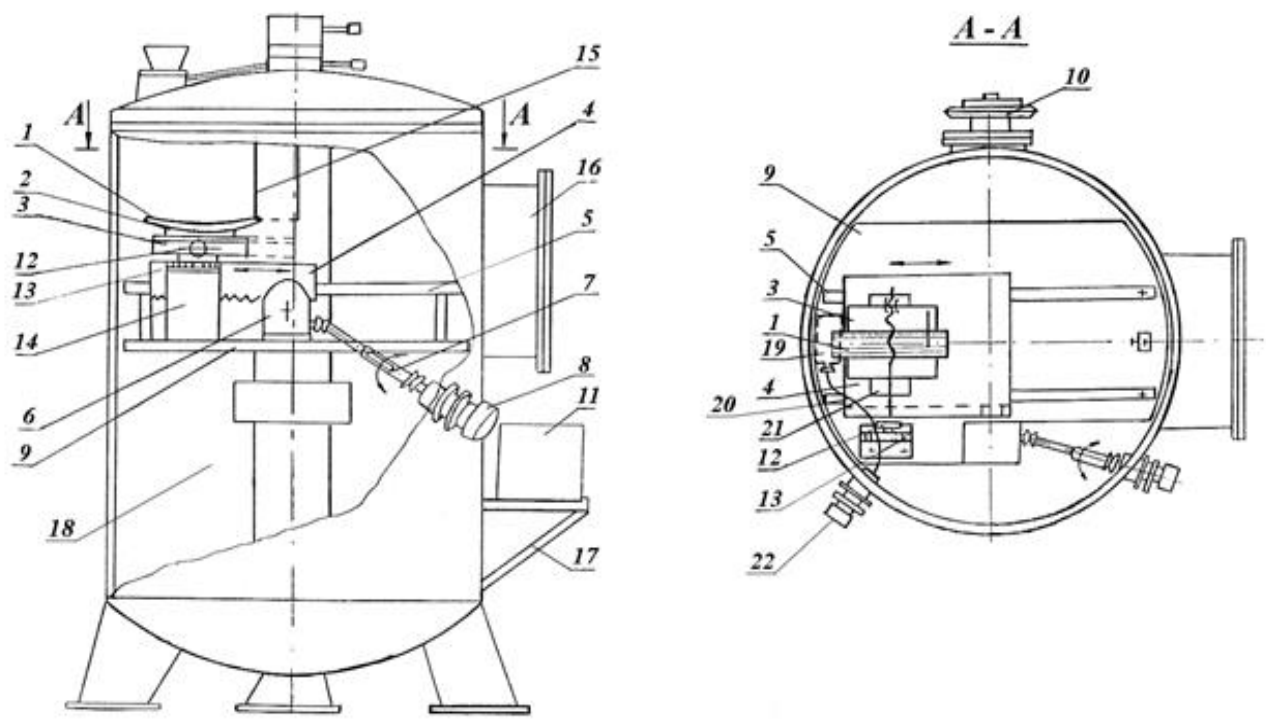

Figure 4. The manipulator in the installation for plasma spraying: 1 - sprayed part; 2 - device for fixing inserts; 3 - transverse carriage; 4 - longitudinal carriage; 5 - guides of the longitudinal carriage;

6 - worm gear; 7 - sliding driveshaft; 8 - electric motor; 9 - manipulator table; 10 - table lifting drive;

11 - control unit; 12 - free wheeling mechanism; 13 - rake; 14 - stand; 15 - plasma jet;

16 - loading and viewing hatch; 17 - bracket; 18 - vacuum chamber; 19 - worm gear; 20 - flexible shaft; 21 - guides of the cross-carriage; 22 - motor drive rotation 


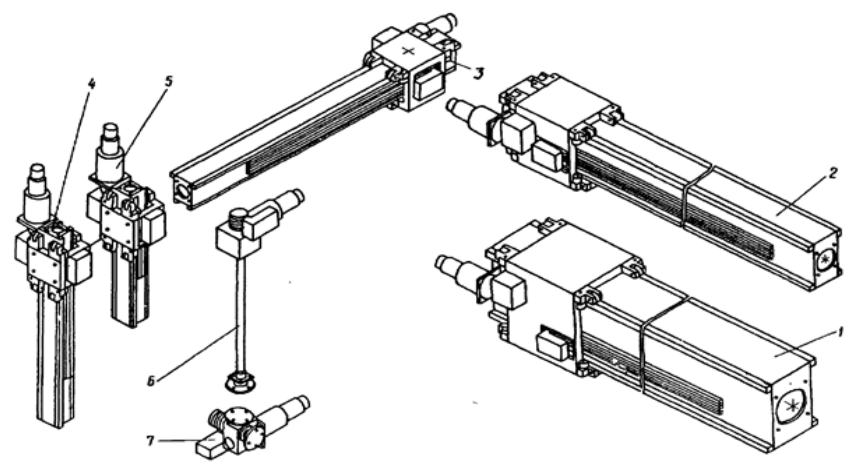

Figure 5. A set of UD 375 modules for upgrading the system for moving products of the installation for plasma spraying: 1, 2, 3, 4, 5 - for rectilinear movement over different distances; 6 - for rotation; 7 - for tilt

Due to the need to spray the increasingly complex surfaces configuration and the requirements of increasingly accurate positioning or uniform movement of articles, software controlled electric drive systems are used. Such devices include, for example, E. A. Patona IES designs for controlling the movement of welding tools. Successful technical solutions in these developments, presented in Fig. 5, made it possible to apply them in systems of product movement in plasma spraying plants after quite simple modernization, consists in design of elements of transition to the table with deposited product.

Recently, systems for moving the built-up article have been using computerized electric drives with collector-free electric motors - stepping and valve motors. Such electric drive systems allow operating and mounting movements to be controlled without the use of downshift gears. Effects are achieved as follows:

1. high reliability due to absence of a collector-brush unit;

2. small mass-dimensional characteristics and inertia (no reduction gear box);

3. accuracy of programmed parameters for positioning and reproducing the trajectory of the specified trajectory, including variation of distance from the nozzle of the plasmatron to the article and off-axis oscillations of the article with increased frequencies to obtain, among other things, a high-quality wide-layer coating.

The selection and programming of an adjustable electric drive to provide new possibilities of operating the manipulators of plasma spraying plants requires a special approach. One embodiment of such an approach may be to use a valve motor drive both to work out a predetermined angle of rotation of the engine shaft of the powder dispenser and to control the movements of the manipulator.

Development of the model of the automatic control system for the position of the motor shaft. In order to assess the possibility of working out the sequence of pulses, a model of the automatic control system (ACS) for the position of the motor shaft was developed to change the angle of rotation of the valve motor shaft to control the dosing of powder into the plasmatron and control the working and setting movements of the manipulators.

The system of equations describing transients in the system is as follows: 


$$
\left\{\begin{array}{l}
M-M_{c}=J \cdot p w \\
I=\frac{(U-E)}{R_{g} \cdot\left(T_{g} \cdot p+1\right)} \\
U=\frac{\left(U_{3 i}-U_{i} \cdot K_{3 i}\right) \cdot K_{p e z . i} \cdot K_{n p}}{T_{m} \cdot p+1} \\
M=I \cdot K_{\Phi} ; \\
U_{3 \mathrm{i}}=\left(\varphi^{*}-\varphi \cdot K_{\text {3. }}\right) \cdot W_{p e z . \varphi}(\mathrm{p}) \\
E=K_{\Phi} \cdot w
\end{array}\right.
$$

where: $\varphi^{*}, \varphi-$ set the engine shaft angle of rotation is also given; $w$ - engine rotation speed; $U_{3 i}$ is current contour task tension, $\mathrm{B} ; U_{i}-$ voltage corresponding to current turnover, $\mathrm{B}$; $K_{\mathrm{pc}}= \pm 1$ - polarity of the value of the factor of the current regulator depends on the value of the dead zone $( \pm 0.5 \mathrm{~B})$ and the polarity of the signal at its input; $\mathrm{K}_{\text {пр }}=24$ is the transfer factor of the converter; $U$ - output voltage of converter, $\mathrm{B} ; E$ is electromotor force of electric motor, $\mathrm{B}$; $I$ - motor current, $\mathrm{A} ; \mathrm{K}_{3 \mathrm{i}}=2$, is the current feedback factor; $\mathrm{K}_{3 \mathrm{w}}=0.25$ - feedback coefficient on speed; $\mathrm{K}_{\phi}=0.99 \mathrm{~B} \bullet \mathrm{c},-$ design coefficient of electric motor; $T_{\mathrm{m}}=0.0001 \mathrm{~s}$, - converter time constant; $R_{\mathrm{r}}=1 \mathrm{ohm},-$ active resistance of electric motor in heated state; $T_{\mathrm{r}}=0.0005 \mathrm{~s}-$ an electric motor phase time constant; $J=0.0021 \mathrm{~kg} \bullet \mathrm{m}^{2}$ - total moment of inertia reduced to the engine shaft; $M$ - electromagnetic moment of electric motor; $M_{\mathrm{c}}=2.5 \mathrm{H} \cdot \mathrm{m}-$ static moment on the motor shaft; $p$ is a Laplace operator.

Taking into account the requirements of the technological process for the accuracy of the specified movements during synthesis of the double-circuit ACS with the relay current regulator, the standard setting of the external position contour to the symmetrical optimum was used [12]. As a result of synthesis, PD-regulator of position circuit with transfer function $W_{\text {рег. }}(p)$.

Standard model of DC valve electric drive [13] was used during simulation of ACS of subordinate control. The results of mathematical simulation of ACS operation at pulse signal are shown in Fig. 6.

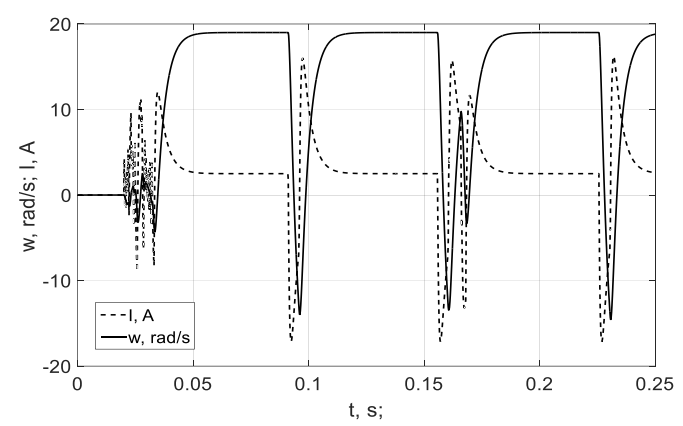

a)

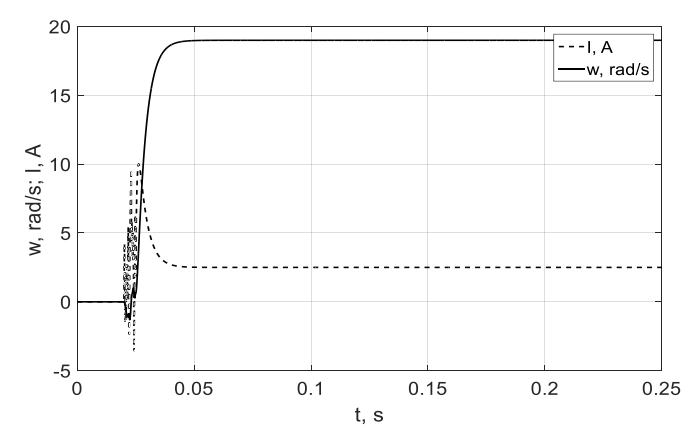

c)

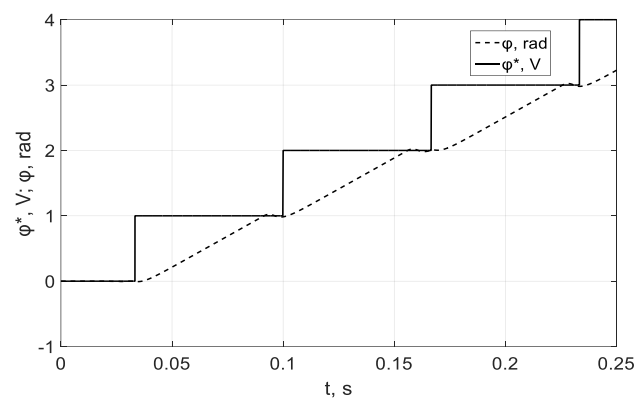

b)

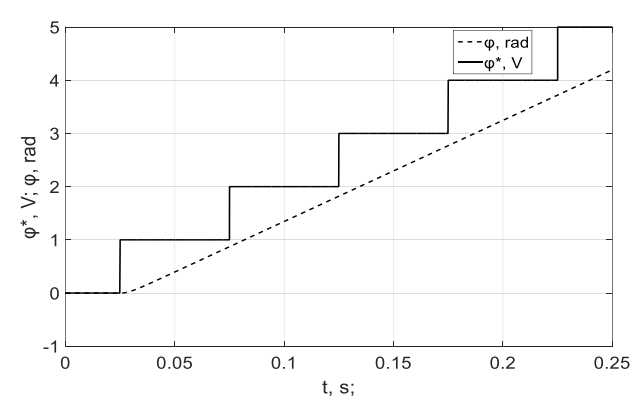

d)

Figure 6. Results of mathematical modeling of transient processes of the automatic control system 
Analysis of results of ACS simulation showed that development of engine shaft rotation angle by $1 \mathrm{rad}$ per pulse is possible at maximum frequency of periodic frequency of rectangular pulses of mission signal in $16 \mathrm{~Hz}$. At the frequency of $20 \mathrm{~Hz}$ in the continuous feed pulse mode, the engine shaft rotation angle of 1 rad per pulse could not be worked out by the system (Fig. $6 \mathrm{c}, 6 \mathrm{~d}$ ). In this mode, the system can provide smooth operating and positioning movements of the manipulators. This means that by changing the frequency and amplitude of the pulses, the system task can provide the necessary modes of operation of the movable components of the equipment for plasma spraying of the blades of gas turbine engines and plants when generating the pulse signal of the task.

Methods of evaluation of spraying results. The results of spraying should be objectively evaluated, and there are a number of methods of such evaluation [14], including the most simple, for example visual. Equipment evaluation techniques, such as wear testing are used for more accurate evaluation. Such tests show that the ring wear resistance of coatings increases by $1.2 \ldots 1.3$ times.

One of the methods being developed is to evaluate the thermal stability of the coating with special laboratory studies, in which samples with the applied coating are repeatedly heated and cooled in the range of operation temperatures of $20 \ldots 1200^{\circ} \mathrm{C}$. The criterion of thermal stability is the condition of the coating after testing, in particular, absence of cracks and peeling from the substrate. Currently, a method for obtaining an evaluation of the quantitative effect of individual parameters, such as the ratio of coating thickness to substrate, their stiffness (modulus of elasticity), etc. on the mechanical characteristics of the sprayed layer. This method is described in detail in the published material [15].

Conclusions. Plasma spraying plants have become widespread enough to improve the performance of assemblies and parts in many devices, particularly when operating under extreme conditions. The efficiency of the plants depends not only on the materials used, but also to a large extent on the perfection of the technical solutions used. The main areas of improvement of plasma spraying plants should be considered:

- increase of energy capacity due to new design solutions;

- increase of plant operation reliability due to application of new materials, new cooling schemes and structural arrangements;

- solving the problem of plasma flux concentration;

- expansion of technical and technological capabilities of plants.

The capabilities of the modern elemental base in plasma spraying units should be increasingly used. The use of the valve motor in the pulse mode of its operation makes it possible to control the dosing of powder supply to the plasmatron and to control the working and installation movements of the manipulators of the plasma spraying unit.

\section{References}

1. Budynovskyy S. A., Chubarov D. A., Matveev P. V. Sovremennye sposoby naneseniya teplozashchytnykh pokrytij na lopatky ha-zoturbynnykh dvyhateley (obzor). Avyatsyonnye materyaly i tekhnolohii. 2014. № S5. P. 38-44. doi: 10.18577/2071-9140-2014-0-s5-38-44. https://doi.org/10.18577/2071-9140-2014-0-s5$38-44$

2. Hryhor'ev S. N., Kovalev O. B., Kuz'myn V. Y., Mykhal'chenko A. A., Sokolova N. H., Fomyn V. M. Novye vozmozhnosty tekhnolohii plazmennoho napyleniya iznosostojkikh pokrytij. Trenije i iznos. 2013. T. 34. № 3. P. 221-226.

3. Pfender L. F. Trends in Thermal Plasma Technology. Thermal Plasma Torches and Technologies / edited by Solonenko O. P. Cambridge International Science Publishing. Plasma Torches. Basic Studies and Design. 2003. Vol. 1. P. 20-41.

4. Lebedev V. A., Loi S. A. Modernyzatsyia plazmotrona dlia napylenija na vozdukhe i v kontrolyruemoj atmosfere (v vakkume). Visnyk Natsionalnoho tekhnichnoho universytetu "KhIII". Seriia: Novi rishchennia v suchasnykh tekhnolohiiakh. № 10. 2019. P. 21-29. 
5. Kuzmyn V. Y., Kartaev E. V., Serhachev D. V., Kornyenko E. E. Plazmennoe napylenije poroshkovykh pokrytji prs hazodynamycheskoi fokusirovke dispersnoj fazy. Aktualnye problemy v mashynostroenii: materyaly 1-j mezhdunarodnoj nauchno-prakticheskoi konferentzii / pod red. V. Yu. Skyby. Novosibirsk: Izd-vo NHTU, 2014. P. 482-488.

6. Mykheev A. E., Girn A. V., Ravodina D. V., Jakubovych Y. O. Plazmotron dlia nanesenia pokrytij iz tuhoplavkikh dyspersnykh materialov. Sybyrskij zhurnal nauky i tekhnolohii. 2018. T. 19. № 2. P. 365-372.

7. Ignatyk A. V., Ivanov A. Y., Smirnov A. N., Shorikov V. S. Plazmennye ustroistva dlia nanesenyia pokrytij raznoho funktzionalnogo naznachenija. Aktualnyje problemy aviatzii i kosmonavtiki. Tekhnicheskije nauki. 2010. P. 10-11.

8. Guessasma S., Montavon G., Coddet C. Modeling of the APS Plasma Spray ProcessUsing Artificial Neural Networks: Basis, Requirements andan Example. Computational Materials Science. 2004. Vol. 29 (3). P. 315-333. doi: 10.1016/j.commatsci.2003.10.007. https://doi.org/10.1016/j.commatsci.2003.10.007

9. Romakin N. E. Mashyny nepreryvnoho transporta: ucheb. posobiee dlia stud. vyssh. ucheb. Zavedenij. M.: Akademia, 2008. 432 p.

10. Paton B. E. Problemy kompleksnoj avtomatizatzii svarochnoho proizvodstva. Avtomaticheskaija svarka. 1981. № 1. P. 3-9.

11. Ekelof B. Adaptiv malti-run submerged-are technology. Svetsaren. 1998. № 1. P. 3-6.

12. Leonhard W. Control of Electrical Drives, 2nd edition. Springer. Berlin, 1996. https://doi.org/10.1007/9783-642-97646-9

13. Lebedev V. A., Hulyj M. V. Bystrodeistvujushchijventilnyj elektroprivod dlia oborudovanija mekhanysirovannoi duhovoj svarki. Mekhatronika. Avtomatisazia. Upravlenie. 2014. № 6. P. 47-51.

14. Kuzmin V. I. et al. Comparison of Thermophisical and Optical Methods of Temperature Distribution Measurements in Flow of Plasmatron with Interelectrode Inserts. Изв. вузов. Физика. 2007. Т. 50 , № 9. C. $85-88$.

15. Lebedev V. A., Loi S. A. Modelirovanije stoikosti plazmennoho napylenija lopatok hazoturbinnykh dvihatelej i ustanovok. Model question of production and repair in in-dustry. Materials of the 19th International Scientific fnd Technical Seminar. (February 18-23, Kosice, Slovak Republic). P. 97-99.

\section{Список використаної літератури}

1. Будиновский С. А., Чубаров Д. А., Матвеев П. В. Современные способы нанесения теплозащитных покрытий на лопатки газотурбинных двигателей (обзор). Авиационные материалы и технологии. 2014. № S5. C. 38-44. doi: 10.18577/2071-9140-2014-0-s5-38-44. https://doi.org/10.18577/2071-91402014-0-s5-38-44

2. Григорьев С. Н., Ковалев О. Б., Кузьмин В. И., Михальченко А. А., Соколова Н. Г., Фомин В. М. Новые возможности технологии плазменного напыления износостойких покрытий. Трение и износ. 2013. T. 34. № 3. C. 221-226.

3. Pfender L. F. Trends in Thermal Plasma Technology. Thermal Plasma Torches and Technologies / edited by Solonenko O. P. Cambridge International Science Publishing. Plasma Torches. Basic Studies and Design. 2003. Vol. 1. Р. 20-41.

4. Лебедев В. А., Лой С. А. Модернизация плазмотрона для напыления на воздухе и в контролируемой атмосфере (в ваукуме). Вісник Національного технічного університету «ХІІІ». Серія: Нові ріщення в сучасних технологіях. № 10. 2019. С. 21-29.

5. Кузьмин В. И., Картаев Е. В., Сергачев Д. В., Корниенко Е. Е. Плазменное напыление порошковых покрытий при газодинамической фокусировке дисперсной фазы. Актуальные проблемы в машиностроении: материалы 1-й международной научно-практической конференции / под ред. В. Ю. Скибы. Новосибирск: Изд-во НГТУ, 2014. С. 482-488.

6. Михеев А. Е., Гирн А. В., Раводина Д. В., Якубович И. О. Плазмотрон для нанесения покрытий из тугоплавких дисперсных материалов. Сибирскийжурнал науки и технологий. 2018. Т. 19. № 2. C. 365-372.

7. Игнатик А. В., Иванов А. И., Смирнов А. Н., Шориков В. С. Плазменные устройства для нанесения покрытий разного функционального назначения. Актуальные проблемы авиации и космонавтики. Технические науки. 2010. С. 10-11.

8. Guessasma S., Montavon G., Coddet C. Modeling of the APS Plasma Spray ProcessUsing Artificial Neural Networks: Basis, Requirements andan Example. Computational Materials Science. 2004. Vol. 29 (3). P. 315-333. doi: 10.1016/j.commatsci.2003.10.007. https://doi.org/10.1016/j.commatsci.2003.10.007

9. Ромакин Н. Е. Машины непрерывного транспорта: учеб. пособие для студ. высш. учеб. Заведений. М.: Академия, 2008. 432 с.

10. Патон Б. Е. Проблемы комплексной автоматизации сварочного производства. Автоматическая сварка. 1981. № 1. С. 3-9. 
11. Ekelof B. Adaptiv malti-run submerged-are technology. Svetsaren. 1998. № 1. P. 3-6.

12. Leonhard W. Control of Electrical Drives, 2nd edition. Springer. Berlin, 1996. https://doi.org/10.1007/9783-642-97646-9

13. Лебедев В. А., Гулый М. В. Быстродействующий вентильный электропривод для оборудования механизированной дуговой сварки. Мехатроника. Автоматизация. Управление. 2014. № 6. C. $47-51$.

14. Kuzmin V. I. et al. Comparison of Thermophisical and Optical Methods of Temperature Distribution Measurements in Flow of Plasmatron with Interelectrode Inserts. Изв. вузов. Физика. 2007. Т. 50 , № 9. C. $85-88$.

15. Lebedev V. A., Loi S. A. Modelirovanije stoikosti plazmennoho napylenija lopatok hazoturbinnykh dvihatelej i ustanovok. Model question of production and repair in in-dustry. Materials of the 19th International Scientific fnd Technical Seminar. (February 18-23, Kosice, Slovak Republic). P. 97-99.

\title{
УДК 621.793.72
}

\section{ВДОСКОНАЛЕННЯ ОБЛАДНАННЯ ДЛЯ ПЛАЗМОВОГО НАПИЛЕННЯ ЛОПАТОК ГАЗОТУРБІННИХ ДВИГУНІВ І УСТАНОВОК}

\author{
Володимир Лебедєв ${ }^{1}$; Сергій Лой²; Олексій Халімовський ${ }^{3}$ \\ ${ }^{1}$ IEЗ імені С. О. Патона НАН України, Київ, Украӥна \\ ${ }^{2}$ Херсонська філія Миколаївського кораблебудівного університету \\ імені Адмірала Макарова, Херсон, Україна \\ ${ }^{3}$ Національний технічний університет України «Київський політехнічний \\ інститут імені Ігоря Сікорського», Київ, Украӥна
}

\begin{abstract}
Резюме. Розроблено нові конструктивні рішення обладнання для плазмового напилення лопаток газотурбінних двигунів і установок. Застосування такого обладнання дозволяс розиирити сферу його застосування для створення оптимальних умов переносу матеріалу, шуо напилясться на робочу поверхню виробу. При цьому поліпшуються фізичні характеристики та структура напиленого прошарку. Розглянуто основні напрями вдосконалення техніки й технології плазмового напилення на прикладах ряду нових ефективних розробок. Зроблено висновок про те, щзо багатосекиійні конструкиії плазмотронів $\epsilon$ ефективнішими порівняно з традиційними рішеннями. Модернізація обладнання плазмового напилення проведена для двох основних типів плазмотронів: для напилення на повітрі $i$ для напилення 6 контрольованій атмосфері (в вакуумі). На базі плазмотрона ПН-14М розроблено його вдосконалену конструкцію для усунення конструктивних недоліків. Запропоновані конструктивні рішення дозволили зробити конструкцію універсальною щзод середовища застосування. Модернізований плазмотрон має порівняно невеликі витрати плазмоутворюючого газу в робочих режимах. Спеціально розроблена насадка для плазмотрона другого типу, щчо застосовується для напилення в контрольованій атмосфері, дозволила поліпшити його експлуатаційні властивості. Рівномірна подача порошку у плазмотрон реалізується за допомогою дозатора нової конструкиії. При напиленні в контрольованій атмосфері розроблений порошкоживильник забезпечує рівномірну подачу порошків дисперсністю як більше, так і менше 40 мкм. Для зменшення (відсутності) залипання порошку запропоновано використання вентильного двигуна. Дослідження розробленої системи автоматичного керування положенням валу вентильного двигуна проводилося в діапазоні зміни частот імпульсного сигналу завдання до 20 Гц. Результати математичного моделювання підтвердили можливість використання вентильного двигуна в імпульсному режимі його роботи для управління дозуванням подачі порошку у плазмотрон та управління робочими й установлюваними переміщеннями маніпуляторів установки для плазмового напилення.
\end{abstract}

Ключові слова: плазмове напилення, лопатка, газотурбінний двигун, установка, процес, вдосконалення, техніка, технологія. 